\title{
Artelogie
}

Recherche sur les arts, le patrimoine et la littérature de l'Amérique latine

$7 \mid 2015$

Photographie contemporaine en Amérique latine

\section{Specters of brazilian history in the early photographic work of Mario Cravo Neto}

Alice Heeren

\section{Q OpenEdition}

\section{Journals}

Electronic version

URL: https://journals.openedition.org/artelogie/1158

DOI: 10.4000/artelogie.1158

ISSN: 2115-6395

\section{Publisher}

Association ESCAL

Electronic reference

Alice Heeren, "Specters of brazilian history in the early photographic work of Mario Cravo Neto", Artelogie [Online], 7 | 2015, Online since 15 April 2015, connection on 11 April 2022. URL: http:// journals.openedition.org/artelogie/1158; DOl: https://doi.org/10.4000/artelogie.1158

This text was automatically generated on 11 April 2022

Association ESCAL 


\title{
Specters of brazilian history in the early photographic work of Mario Cravo Neto
}

\author{
Alice Heeren
}

1 Mario Cravo Neto est l'un des photographes contemporains les plus importants du Brésil. Ses œuvres montrent un mariage complexe de lyrisme esthétique, monumentalité sculpturale, et rituels afro-brésilienne. Dans cet article, je suis intéressé par l'approche des sujets et des comparaisons qui d'autres chercheurs de l'œuvre de Cravo Neto ont résisté. En particulier, je me concentre sur la façon dont ses photos vont à l'encontre de la tradition documentaire et ethnographique du Brésil. En regardant une série de travaux antérieurs de Cravo Neto, je soutiens que l'héritage de l'archive du atlantique noir est un courant sous-jacent dans l'œuvre de l'artiste que parfois s'avère de façon éloquente.

\section{Introduction}

Mario Cravo Neto was born in 1947 in the city of Salvador in Bahia. He travelled extensively during his life, spending large periods of time in Europe and North America where he was exposed to a diverse milieu of contemporary artists. He returned to Brazil in 1970 from which time he worked on sculpture and photography and lived in Salvador, Bahia until his death in 2009.

In this study, I focus, particularly, on Cravo Neto's earlier work, the series produced in black and white between 1987 and 1998 and published in the book The Eternal Now edited by the artist and Edward Leffingwell (Leffingwell 2002) by Aries Editora in Brazil. A large format luxurious publication, it has one introductory text by Leffingwell. ${ }^{1}$ As a larger universe, the photographs found in the publication The Eternal Now have some discerning features. First, the images are in their majority portraits of one single subject produced in studio with very few objects and no specific background. The objects that are present are central to the compositions. Secondly, the male body is 
featured prominently, its percentage being 2 to 1 to portraits of women and 3 to 1 to those of children. Finally, the body overwhelms the space of the compositions and the way the artists crops the bodies privileges specific parts of them, he presents essentially bodies in pieces. Scholars of Mario Cravo Neto's work interpret this group of photographs very differently and in order to situate my analysis, which works against the grain of the previous scholarship, I begin in this paper by introducing the literature.

4 The work of the artist has been interpreted through different lenses in Brazil and abroad. Tadeu Chiarelli summarizes well the literature on Cravo Neto when he says that "the photography of Mario Cravo Neto demands for itself the quality of work of auteur, since his photographs of almost predominantly black sitters, presented in hieratic poses, configure a personal interpretation of Afro-Brazilian myths (Chiarelli 2002)." Add to these ideas : firstly the prevailing attention to the sculptural and at times tectonic nature of the bodies presented in the artist's photographs, that Cézar Bartholomeu comments is the very force of Cravo Neto's strategy (Bartholomeu 2007) $i^{2}$ secondly, the attention paid to the mystical evocation of his work as highlighted by Fernando Castro Ramírez and Giulina Scimè (Scimè 2009) ; and thirdly, the familiar nature of the people, and objects, that Cravo Neto collects from his everyday (Leffingwell 2002), and we have a working understanding of the interpretations of Cravo Neto's oeuvre. One question in specific, the role of ritual in the work of Cravo Neto has been the most discussed aspect of his production even though few scholars engage thoroughly with this question. ${ }^{3}$

5 In this paper, I am interested in approaching topics and comparisons that have been resisted by other scholars, even if at times they have been hinted at in this literature. Particularly, I reference the way Cravo Neto's photographs work against the documentary and ethnographic tradition in Brazil, exemplified by the work of photographers such as Cristiano Júnior, Augusto Stahl, and Pierre Verger and the tension between Cravo Neto's images and the history of race in Brazil, particularly in the decades following abolition. These two questions raise others around them, but by outlining constellations of photographs from Cravo Neto's series, I shed light upon them hopefully opening the work for further discussion. Moreover, a larger question I tackle is how do Cravo Neto's images reinvent the black body vis-à-vis the Brazilian nineteenth (and early twentieth-century) photographic archive.

6 I will divide my discussion here in two parts according to constellations of photographs I have delineated. The first group is made up of photographs where the compositional space is overtaken by regions of the black bodies : the neck and the back, specifically. I want to analyze how these images confront the polygenic and pseudo-scientific discourse embodied by ethnographic images. I will turn to the images August Stahl produced for Louis Agassiz in the 1860s as sources of comparison. Some of the questions I am faced with are : Why is the effacement of identity, particularly through a obscuring of the face, so pervasive in this body of photographs? How does this compositional/formal strategies evoke, even if at times against the artist's intention, ethnographic photography and the use of photography for surveillance in ID and mug shoots? Why are the face and the neck the parts Cravo Neto focuses on? What does these images communicate through their affect?

7 The second constellation I will look at is of women's bodies and images of children. I examine these again against the backdrop of ethnographic photography produced 
during the nineteenth century in Brazil, but I also look at the archive of studio photography and the traditional ways of representing the slave body in them. I will focus on how these images worked in the nineteenth and early twentieth century to communicate racialist discourses, framing the body to a specific spatial (and imaginary) realm. The role of the mãe preta in Brazilian history will be a key feature of this section, as will the role of the mulata's body and her white children in twentiethcentury discourses of racial cleansing. Some of the questions approached in this section are : How does Mario Cravo Neto's photographs dialog with the wider history of AfroBrazilian struggles? Does the discourses of racial democracy and racial cleansing that were widespread in the late nineteenth and early twentieth century bears on this work in ways even the artist could not predict? How does the images push against this history, reconfigure, and subvert it ?

8 I will conclude the paper with a brief elaboration on the implications of these early photographic works of Cravo Neto for the project of reinventing the black body in a manner that works against the grain of the Black Atlantic archive.

It is important to note that comparisons with other art objects from Man Ray's photographs, Brancusi's sculpture, and Pictorialist photography, which directly challenges the aesthetic 'look' of ethnographic photography, are also possible, but I want to focus here on how Cravo Neto's photographs-especially in the contemporary moment in hindsight-works against the history of photography in Brazil, particularly in the nineteenth century bearing on today's photographic production as a specter. Also, comparisons with other photographers from Cravo Neto's era are possible, but again I have chosen to focus on how his work functions against the tradition of photography in Brazil.

My goal is not to argue that it has been Cravo Neto's intention to illustrate, or discuss these wider societal struggles, or to appropriate and subvert the formal strategies of ethnographic photography, but I do want to argue that the former context and the latter imagery is so persistent and pervasive in Brazilian visual culture that it nonetheless pushes itself against and counter poses the photographs of the artist and as such demand a wider discussion of these relationships.

\section{Specters of Ethnographic Photography}


Figure 1 - left, Mario Cravo Neto, Geraldo,1987 and Figure 2 - right, Pituassu, 1983 The Eternal Now (edited by Edward Leffingwell and Mario Cravo Neto
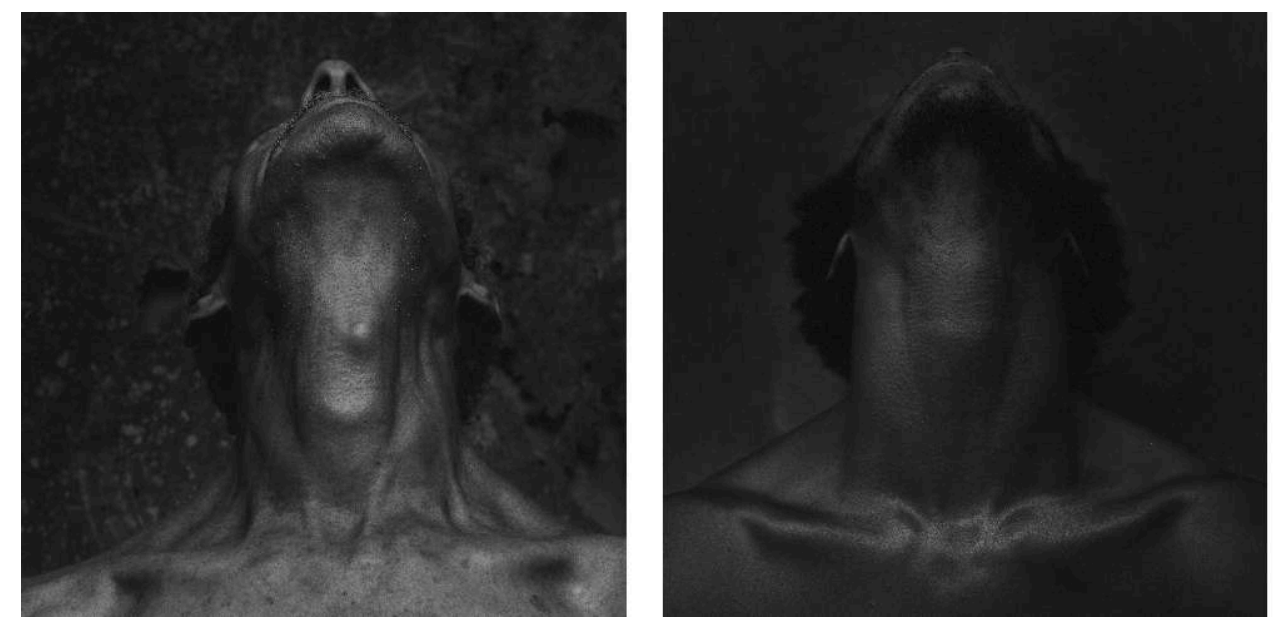

published by Aries Editora in Salvador, Brazil, 2002, Courtesy of Mario Cravo Neto's Estate

In Geraldo of 1987 (Figure 1), and Pituassu of 1983 (Figure 2), two individuals are shown with their heads turned in an upward position exposing their necks. The necks are at the center of the composition while their facial features are not visible, except for the tip of their noses appearing on top of the photograph. Their collarbones and shoulders are highlighted by the strong front facing light that illuminates their bodies. They are like pedestals sustaining one of Brancusi's famous head sculptures. Our gaze is pulled to the neck, the protuberant windpipe, the prominent Adam's apple. The strenuous position cannot help but strike us in its strange reversal of the traditional focus of portrait photography: the face. However, I propose that more than looking at the portrait genre to discuss this image, we should instead turn to a genre constantly avoided in the discussions of Cravo Neto's work: the ethnographic photographs of the Black Atlantic archive.

12 Margarita Medeiros in her article "Between dream and symbol" already notes that: "although he does not make anthropological photography-rather a highly personal form of psychological portraiture-Cravo Neto is very close to the circle of photographerethnographers who have made a study of indigenous tribal and African culture in Brazil. Included in this circle are Maureen Bisiliat and the Frenchman Pierre Verger" (Anderson 1992, 18). Two different questions are raised here, the most important for me being the notion of psychological portraiture, and how Margarita Medeiros places it in opposition to anthropological photography. Now, I certainly agree that Cravo Neto does not produce photographs in a neo-ethnographic manner such as contemporary artist Rineke Dijkstra, who is clearly responding directly to this style.

Nevertheless, in Cravo Neto's images, as Cézar Bartholomeu notes, "the effacement of the face is the trauma of the complete absence of particularity" (Bartholomeu 2007, 26). This is the trauma engendered by ethnographic photography in its reenactment of enslavement. As a common colonial story and as a genre, ethnographic photography is ruled by a paradox, which Christopher Pinney ingenuously identifies: "It is not the fact of being made visible that allows power to play over bodies; rather, it is the act of reinserting the possibility of invisibility in the fact of visibility" (Pinney 2012, 74-5). And here again turning to Bartholomeu we see how this appears and is subverted in Cravo Neto's work: "as identity is annulled in favor of a cultural load that is made aesthetic" 
(Bartholomeu 2007, 24). Thus, I believe, ethnographic photography, particularly of black/slave subjects made in the nineteenth-century in Brazil, haunts Cravo Neto's work and plays an important role in his compositional and aesthetic choices. The neck, and as we will see next, the back, given special attention and highlighting the effacement the face act as punctum ${ }^{4}$ in the image, letting the specter of the Black Atlantic archive peer through.

Ideally set for the observation of "types," ethnographic photography became a key tool in 1844 for the advancement of pseudo-scientificist theories such as polygenics, which advocated different races had different origins and as different species were subjects to hierarchy. This hierarchy of course privileged the "white race" and one of its most prominent defenders was Swiss-born American zoologist Louis Agassiz, who in 1865 travelled to Brazil and commissioned photographers like August Stahl, in order to add this data to his archive in an attempt to legitimize his ideas. The face was the ultimate point of entrenchment in this genre of photography and examples like José Cristiano Júnior's Escravo da Nação Africana Cabinda (Figure 3) are classic examples. The face was the main focus of the images like the latter, first because polygenic used analysis of the cranium and physiognomy to support the premises of their racial discourses, but also because the face was the most useful in the extant process of visual surveillance, semiotic policing and imagistic degradation, which the slaves were continuously subjected to.

Figure 3, José Cristiano Júnior, Escravo da Nação Africana Cabinda, ca. 1865

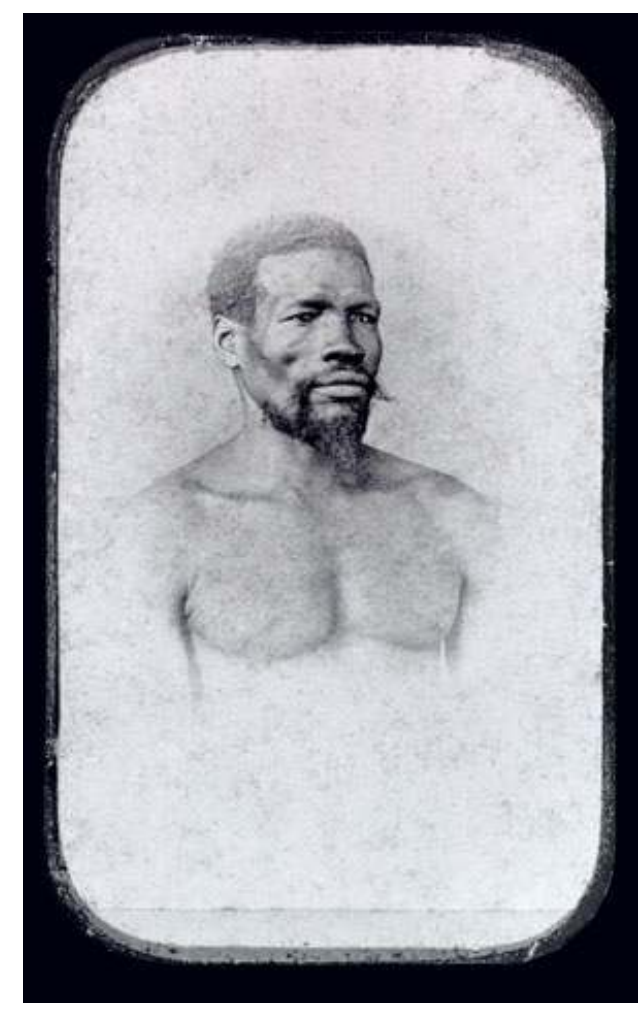

Museu Histórico Nacional do Rio de Janeiro

15 The back also played a key role in this discourse. As Marcus Wood notes: "the half-strip slave body, male or female, created an image with very specific connotations. Slaves were commonly stripped to the waist for one purpose, to be whipped. The frontal and 
profile views of these figures emphasize a significant absence, the backs, which are hidden from our gaze" (Wood 2013, 272). In Cravo Neto, the backs become the center and the whole of the photograph as seen in images like Angela back I (Figure 4) and Francisco back I (Figure ${ }^{5}$ ), both of 1987.

Figure 4, Mario Cravo Neto, Angela back I

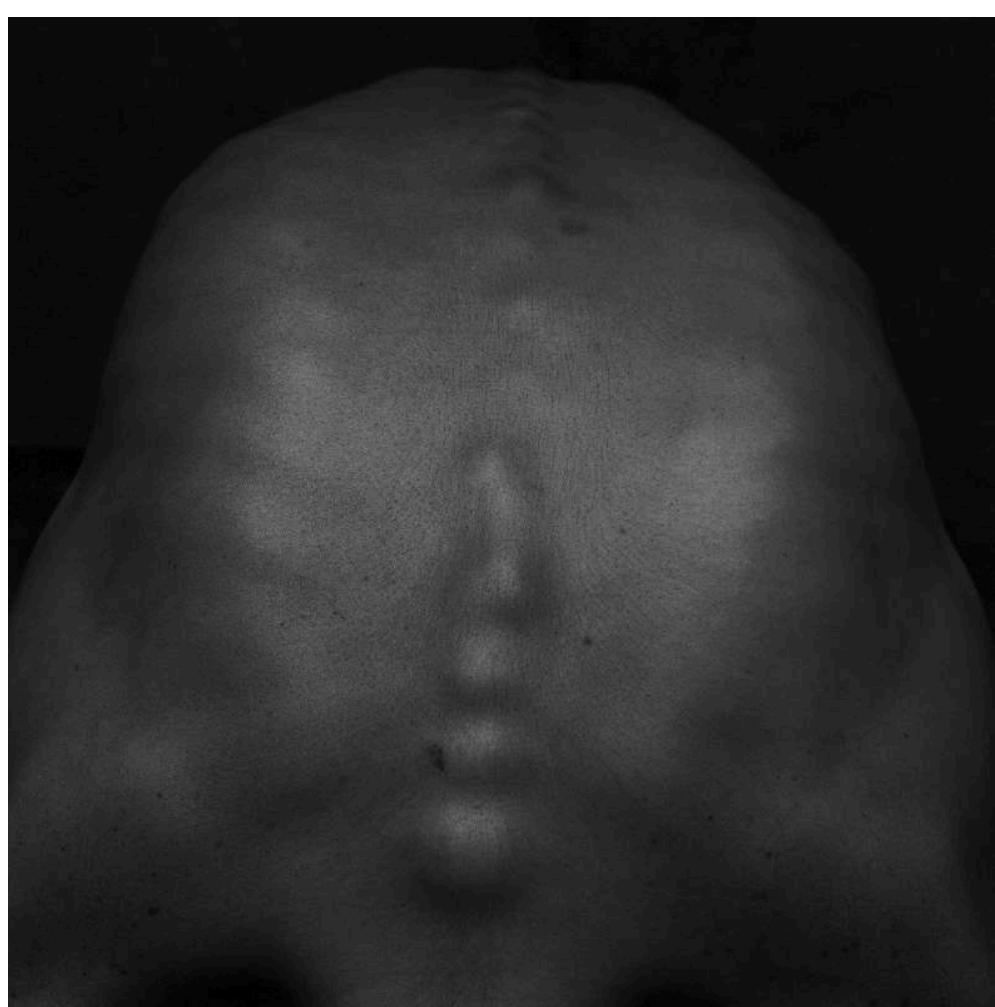




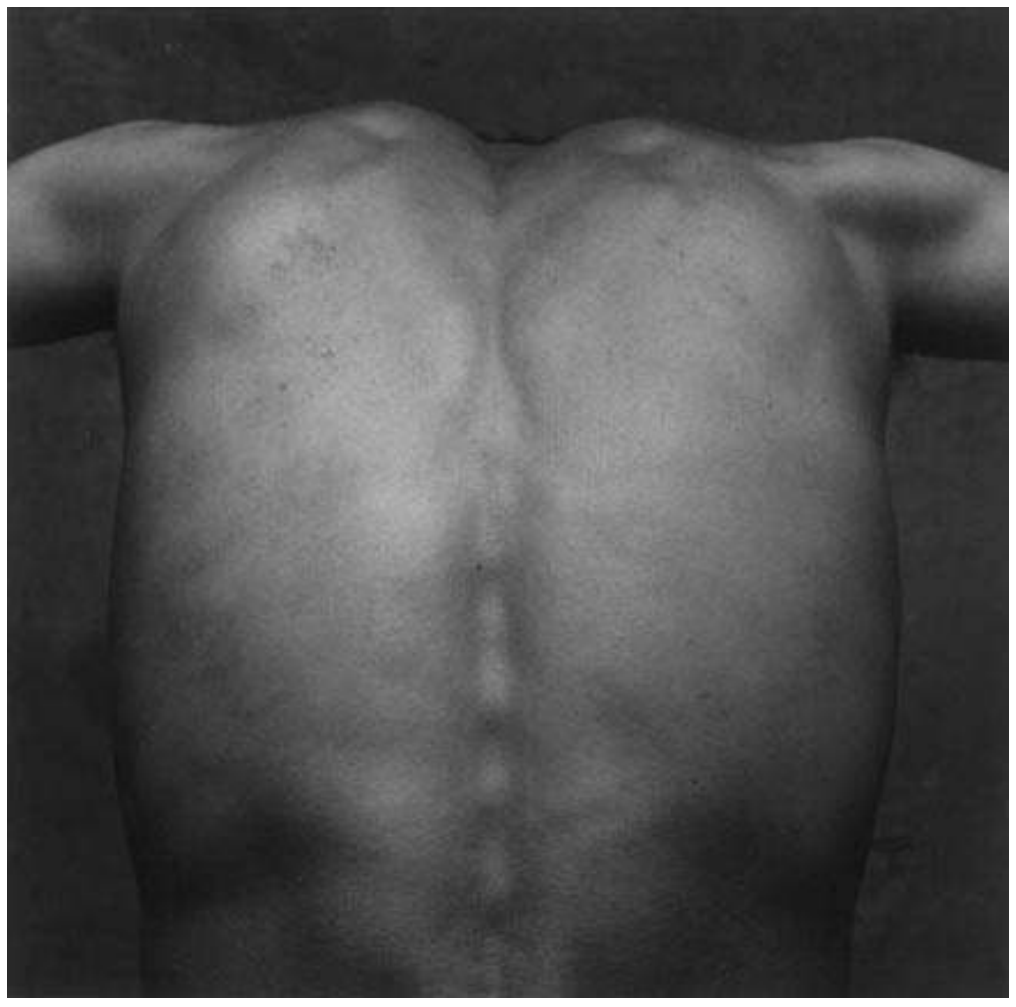

edited by Edward Leffingwell and Mario Cravo Neto, published by Aries Editora in Salvador, Brazil, 2002, Courtesy of Mario Cravo Neto's Estate

The very part of the bodies the slave imagery resisted, Cravo Neto recuperates in his images of backs, while the features ethnographic photography privileged-the facethe artist removes and uses the neck and the top of the head as form of resistance. This second instance can be seen in Tinho I (Figure ${ }^{6}$ ) and II (Figure 7) from 1990. In these, the effacement of the face remains, but the focus is the top of the head with the rest of the body completely erased from the plane.

Figure 6 - left, Mario Cravo Neto, Tinho I and II , Figure 7 - right, The Eternal Now, 1990
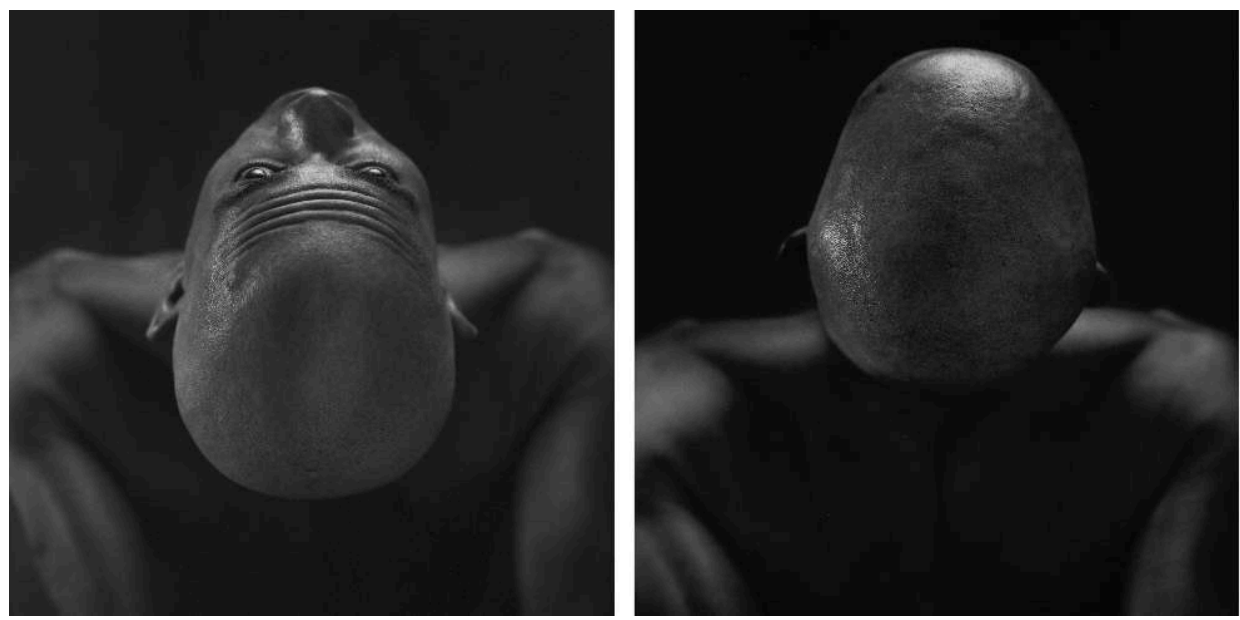

edited by Edward Leffingwell and Mario Cravo Neto, published by Aries Editora in Salvador, Brazil, 2002, Courtesy of Mario Cravo Neto's Estate 
There is yet one other aspect, more traumatic, pornographic, and morbid, that Cravo Neto's images of the black body as a whole resist-the fantasy of the auction block. Again Wood reminds us that "in putting the black human being naked and on display in [the manner of the images of Ausguste Stahl], in so to speak taking the camera on a circumambulatory journey around these bodies, so that they can be peered at, defenseless, and open from all angles, [the images] are unavoidably calling to mind the theatrical and highly charged dynamics of the slave auction" (Wood 2013, 275) Cravo Neto's images remove the black body from this space by charging it with a lyricism that is simultaneously a locus of resistance and a space for the sublime, making them radically different-to the point of calling attention to-images like the ones commissioned by Louis Agassiz from photographer Auguste Stahl (Figure 8 for example).

Figure 8, Auguste Stahl, 'Male Slave Portrait' commissioned by Louis Agassiz, c. 1865

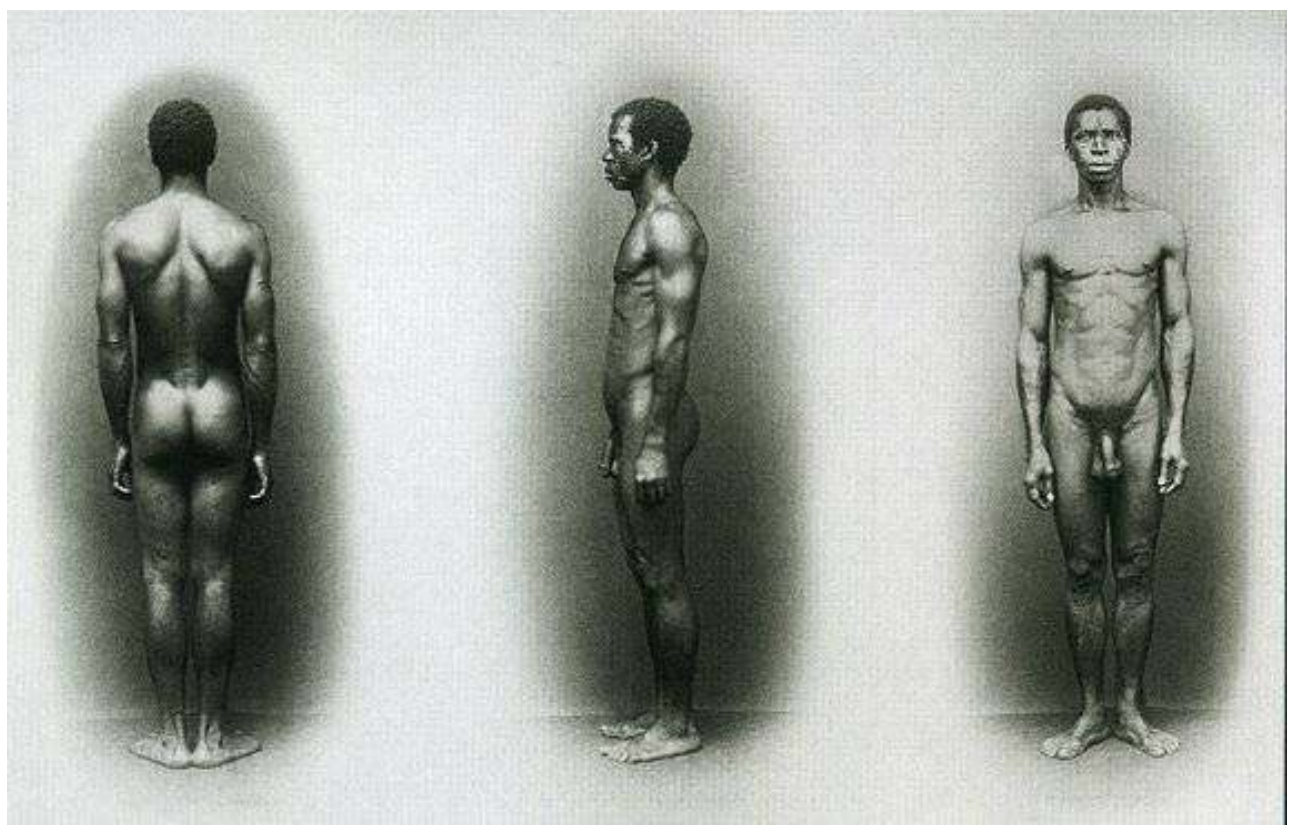

Peabody Museum Harvard University

Nevertheless, Cravo Neto's images also transmit in a manner the affective experience of violence and severance. While the neck as the space where air and nourishment enters the body is submitted to the strenuous position showcased in Geraldo (Figure 1) and Pituassu (Figure 2), rendering the individual unable to absorb nutrients or speak, the process of highlighting the backs as in Angela back I (Figure 5) and Francisco back I (Figure 6) depict a body with severed heads and members, cut at the spine and unable to move or think, or speak. Vocal and spinal cords are severed resulting in an individual that is unable to move and speak, helpless, objectified. Seen against the backdrop of ethnographic photography produced in Brazil during the nineteenth century, Cravo Neto's cluster of body parts of black subjects with the sculptural lyricism and monumental sculpturality, are haunted by the violence and reality of the subjugated black slave body. 


\section{The Mãe Preta and the specters of nineteenth-century ideals of whitening}

19 The second large constellation I am examining here is made up of bodies of female black women and mestiço/white children. One of the most striking and clearly haunting images of Cravo Neto's the Eternal Now series is White Mother of 1990 (figure 9).

Figure 9, Mário Cravo Neto, White Mother, The Eternal Now, 1990

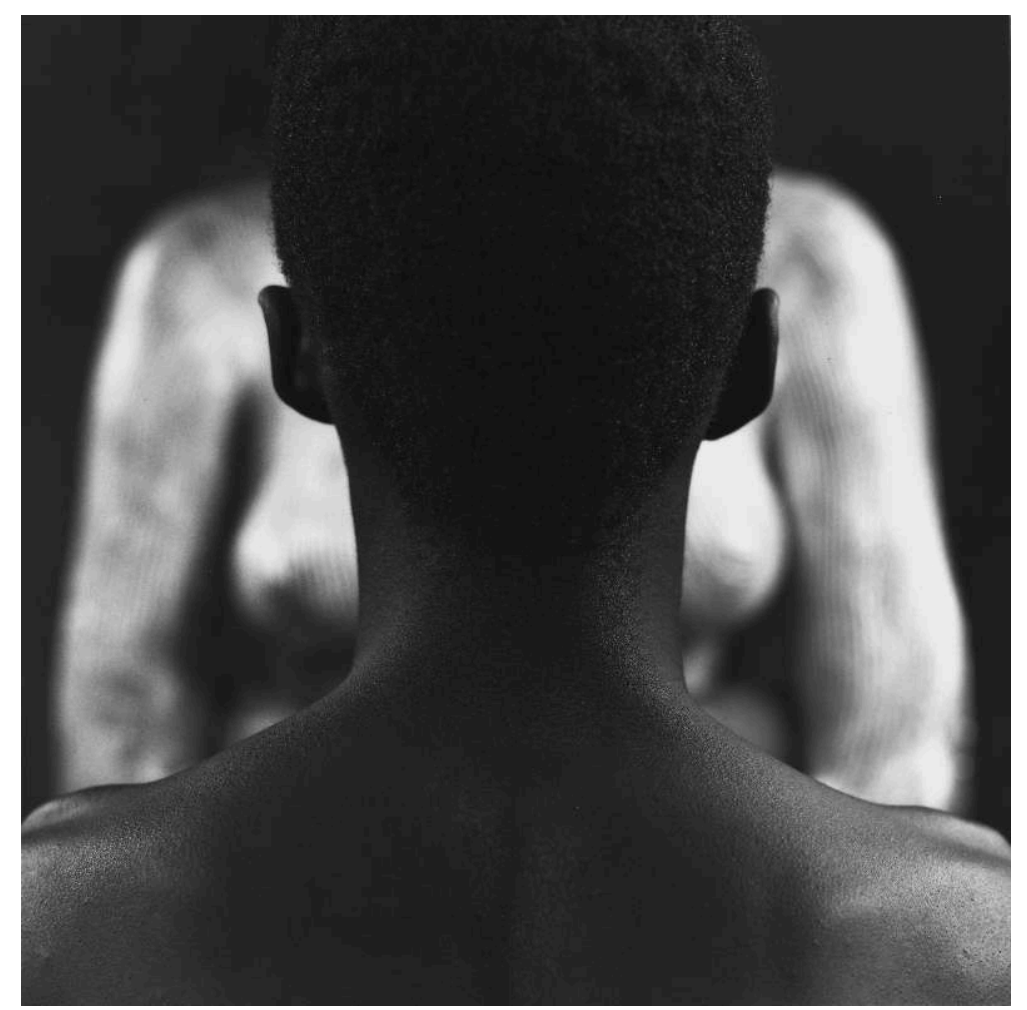

edited by Edward Leffingwell and Mario Cravo Neto, published by Aries Editora in Salvador, Brazil, 2002, Courtesy of Mario Cravo Neto's Estate

20 A photograph showing the back of a black child (or teenager) facing the body of woman, her breasts covered in white paint (likely cal, a preferred white paint for Cravo Neto due to its religious implications), which appear prominently on either side of the child's neck, this image is a central one in The Eternal Now body of work. This duowhite mother as the photograph's title reveal to us-and black child clearly dialogs with the images of the Mãe Preta (or Black Mother), which became a trope of Brazilian nineteenth century photography (Figure 10 is a example). The black mother, enslaved wet-nurses who fed white slave-owner children were extremely common in Brazil and as Wood notes marks a particular traumatic body within the history of slavery in the country. He writes in his book entitled Black Milk: "For four centuries this black milk sustained the progeny of the slave power, which is to say the blood of fertile black women, turned into milk, build up the bodies of the white infants who had been propagated by the slave power" (Wood 2013, 2). 
Figure 10, Photographer Unknown, Mãe Preta with white child. Bahia c. 1870

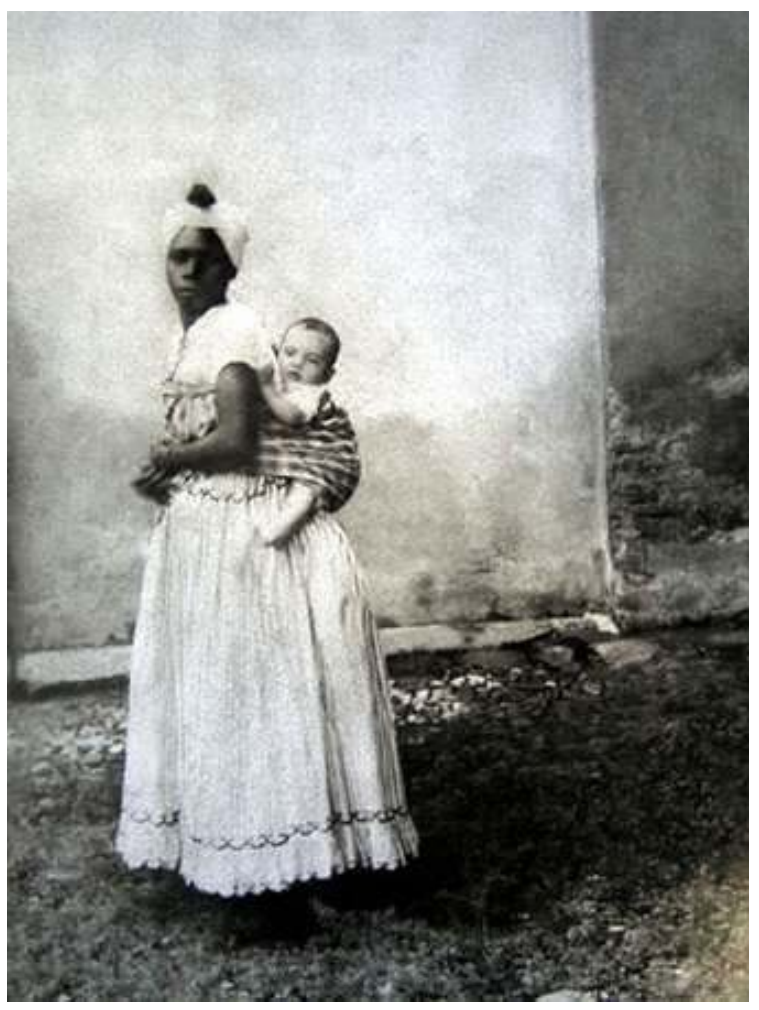

Image from the collection of Instituto Moreira Salles

21 Interestingly, in 1989, just one year before Cravo Neto photographed White Mother, the clothe brand Benetton under the creative direction of Oliviero Tascani had launched in Brazil their highly controversial United Colors of Benetton campaign with the image of a black women with a white child sucking at her breast (Figure 11). The black woman's torso is wrapped in a bright red cardigan, her left breast prominently appearing in the right side of the photograph while she feds the white baby she holds up to her right breast with both hands. The undress torso, yet covered back, the face obscured by the compositional space, the emphatic whiteness and compositional centrality of the child and the blackness of his black mother is clearly haunted by the body of ethnographic photographs I have been discussing here. 
Figure 11, Oliviero Tascani campaign, United Colors of Benetton advertisement, 1989

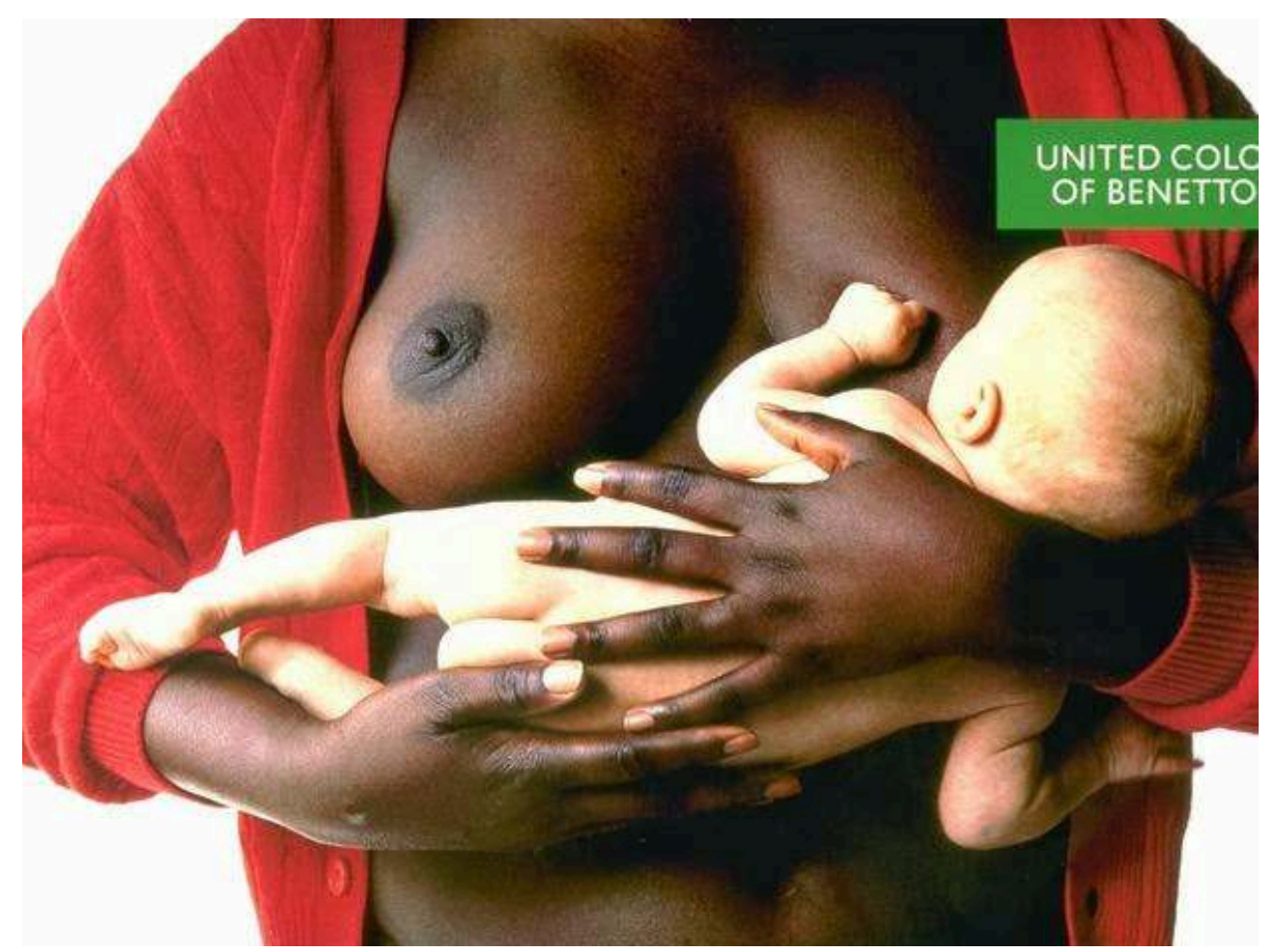

Oliviero Tascani for United Colors of Benetton

Against this backdrop, Cravo Neto's White Mother, and his later piece, Akira profile with talc of 1997 (Figure 12) gain new dimensions. The latter is the image of a white child covered in talc (which echoes the female painted white in White Mother) in profile against the backdrop of a male black body. Interestingly, despite the much prolific United Colors of Benetton campaign that is still running today, the concept of a white child and his black father has not seemed to find its way into this body of imagery. Another question thus comes to the fore, and I argue another aspect of Brazilian racial history peers through in Cravo Neto's imagery. 
Figure 12, Mário Cravo Neto, Akira profile with talc, The Eternal Now, 1997

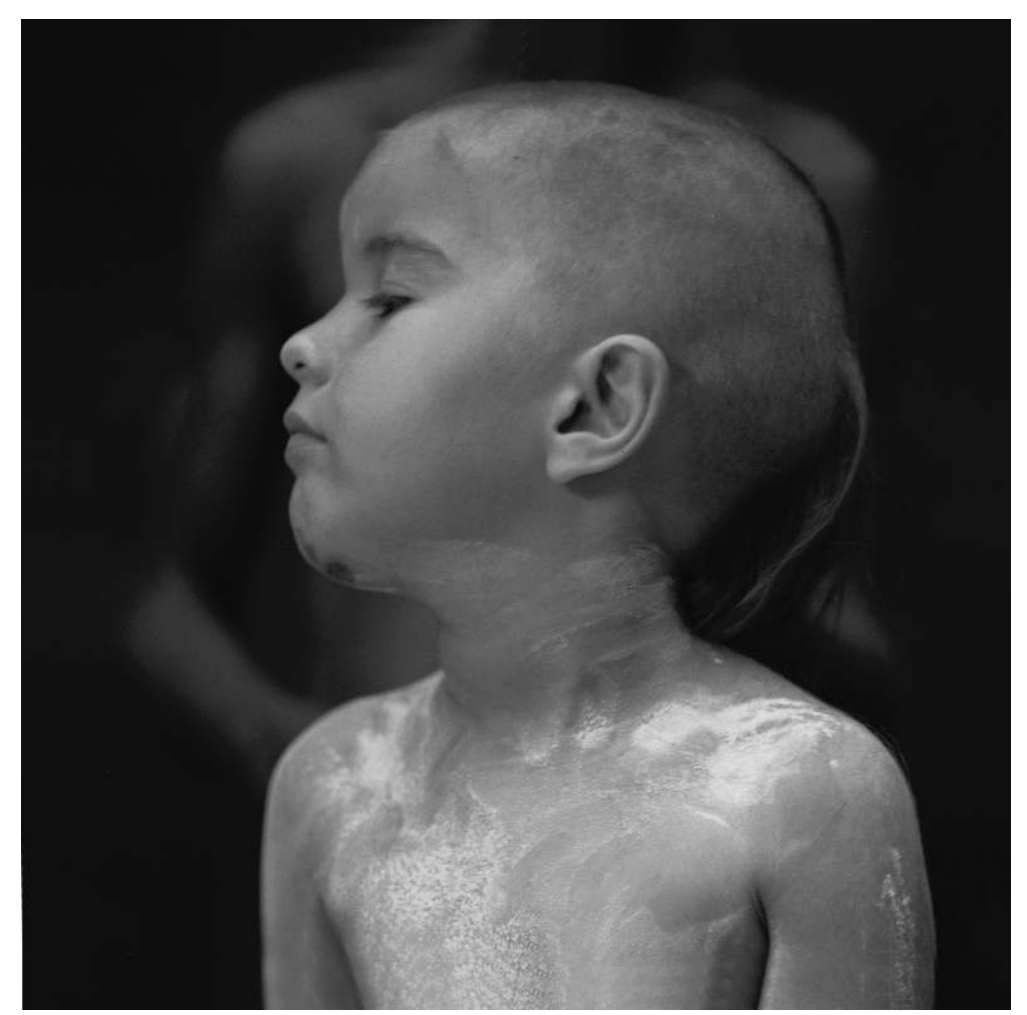

edited by Edward Leffingwell and Mario Cravo Neto, published by Aries Editora in Salvador, Brazil, 2002, Courtesy of Mario Cravo Neto's Estate mulato became prominent in the national racial discourse. Miscegenation was an unavoidable fact of Brazilian society, and because of this, theories of degeneration of the mestiço subject, highly adopted in other former colonies like the United States, were wildly unpopular. Miscegenation became central to the discourse of national identity by being coupled with the ideal of "whitening." $\underline{5}$ "Whitening" as a theory posited that because of the white races' genetic superiority (one discourse supported theoretically by the scientificism of theories like polygenic), it had the possibility to colonize-or the favorite term of the advocates of this theory, acculturate-black bodies and systematically turn them white. In short, a system of sexual exploitation-by the white master of the black female body-already very much part of Brazil since the sixteenthcentury, a history the bodies of Brazilian mulatos inevitably carried, was now elevated to the purifying strategy of the nation. $\underline{6}$ Thus fertile mulata women, and their white children were the future of the country, while the male black active progenitor became the most threatening body for the body politics.

This historical frame haunts images of Cravo Neto in interesting ways. The large number of black male bodies represented in his earlier works, the white children as well as the images of the pregnant and fertile mulata bodies resonate with the history of racial practices in the country, while being extremely personal bodies, individuals of Cravo Neto's own family. This exposes how our own bodies carry histories and wear them like lines in a hand. In the bodies of women of mixed-descendance in Cravo Neto's work like Angela of 1989 (Figure 13), the torsos and breasts are the central features of 
the image. Their fertility is highlighted and emphasized, as in images of pregnant women like Angela and Lukas, Torso with White Feathers of 1989 (Figure 14).

Figure 13, Mário Cravo Neto, Angela

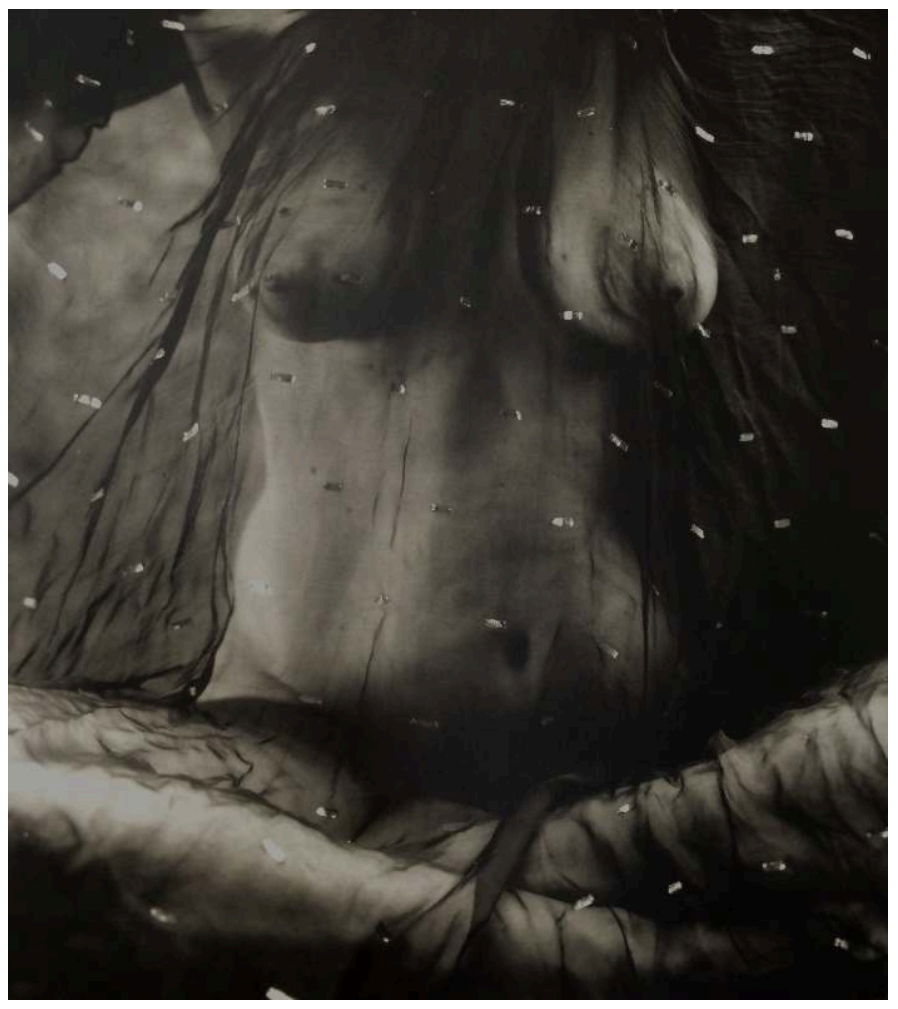


Figure 14, Torso with White Feathers. The Eternal Now, 1989

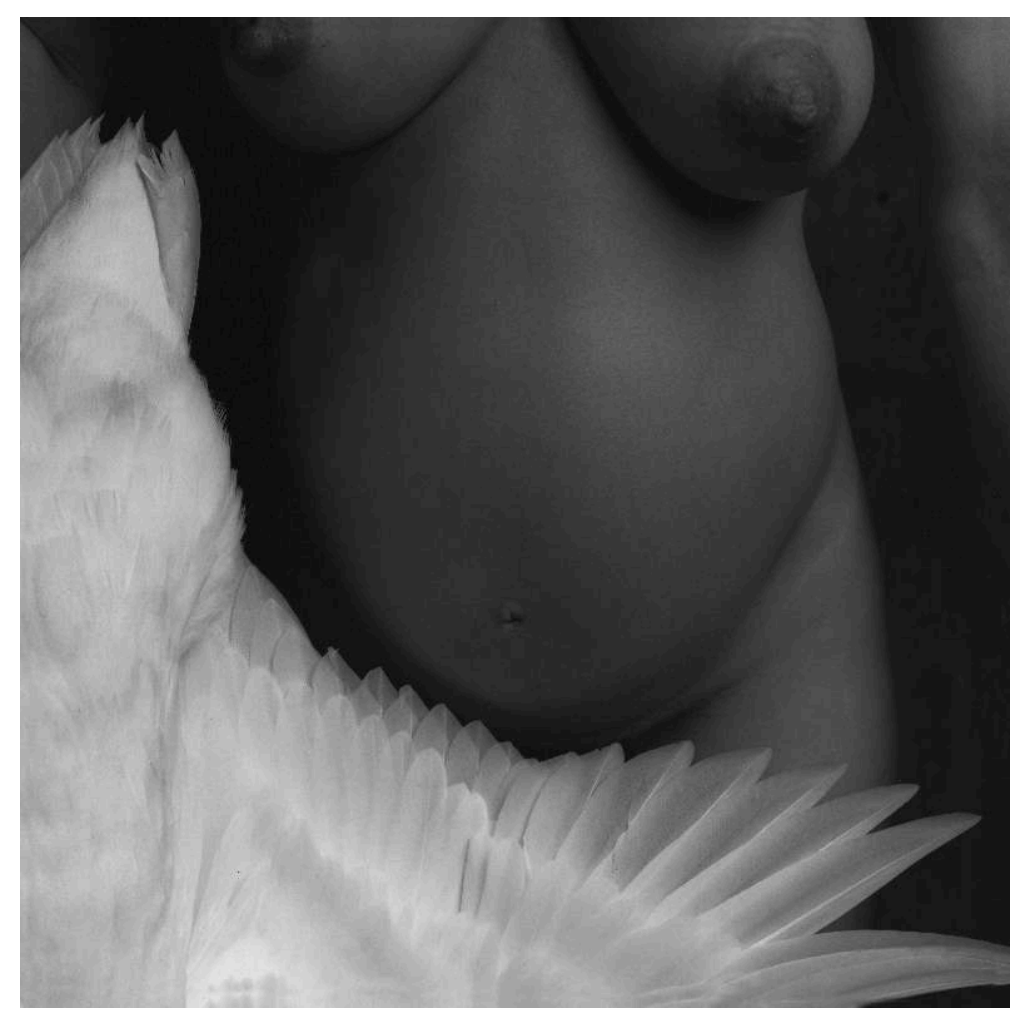

edited by Edward Leffingwell and Mario Cravo Neto, published by Aries Editora in Salvador, Brazil, 2002, Courtesy of Mario Cravo Neto's Estate

24 These mulatas' bodies juxtaposed to the white children in images like Lukas with mirror of 1997 (Figure 15) recall the history of discourses of racial cleansing, but they inevitably also push against it. In Lukas with mirror for instance, the face of the boy is the focus of the composition illuminated by a contrary light that comes from below, from the mirror in which he stares. Framing his head are the hands of a black subject that is not visible in the composition, but is a strong presence nevertheless. 
Figure 15, Mário Cravo Neto, Lukas with mirror, The Eternal Now, 1997

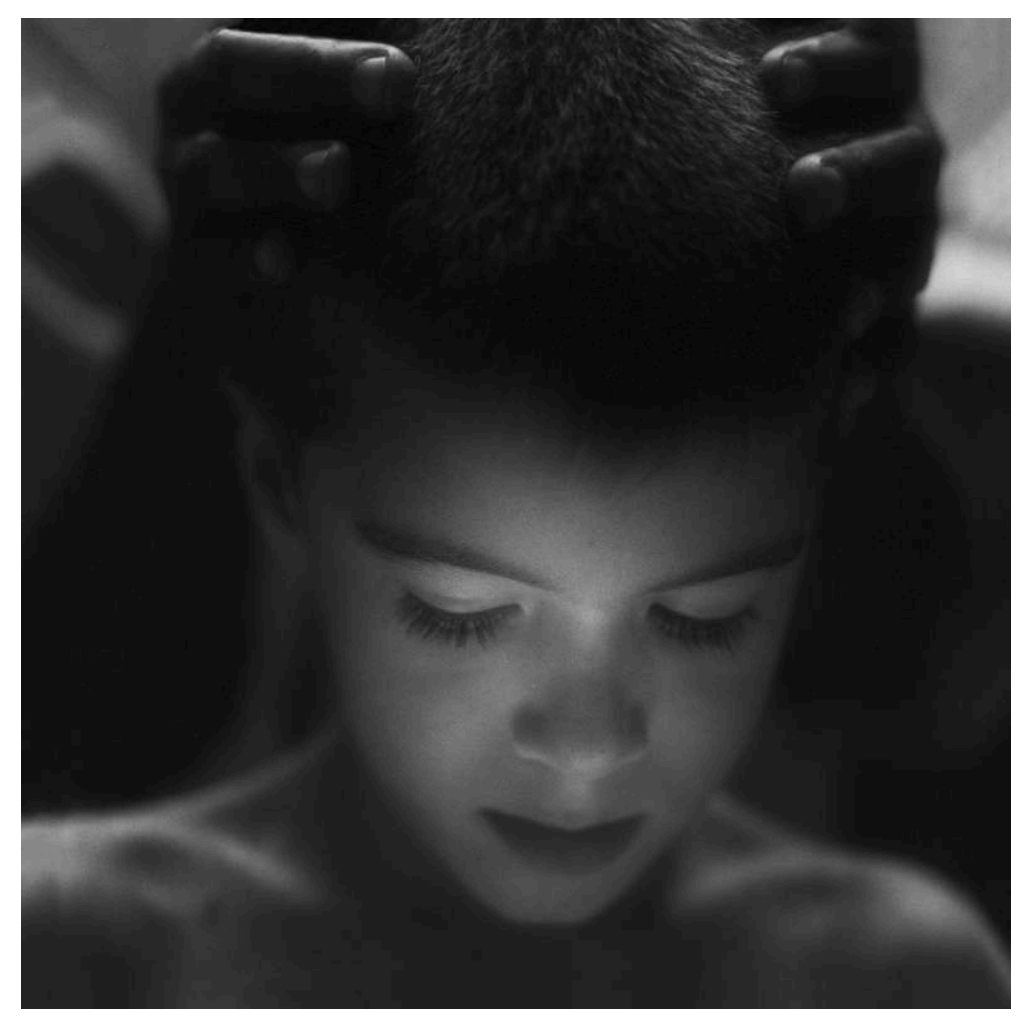

edited by Edward Leffingwell and Mario Cravo Neto, published by Aries Editora in Salvador, Brazil, 2002, Courtesy of Mario Cravo Neto's Estate

The white child is involved in a ritual; he is cradled by the black body, the black tradition and history that bore him. It is interesting that the black body extirpated from the white child-who has been "cleansed," been "whitened" both by genetics and by the social frame that "civilizes" his body and denies his heritage by affirming its inferiority to the white, European tradition-here cradles that child and embeds him in this tradition, returns him to his own black heritage.

This subversive force of Cravo Neto's images again is found in the backgrounds and objects he includes in his compositions. In Akira com pedra de sango of 1992 (Figure 16), for example, Afro-Brazilian rituals are juxtaposed and ingested, one might say, by the white child. In the hand that holds the object the trace of ritual peers through, the upper part of the image reconnecting the child to the tradition that he then ingests and re-assimilates into his body, reincorporates the blackness that has been stripped from him by national ideologies. 
Figure 16, Mário Cravo Neto, Akira com pedra de sango, The Eternal Now, 1992

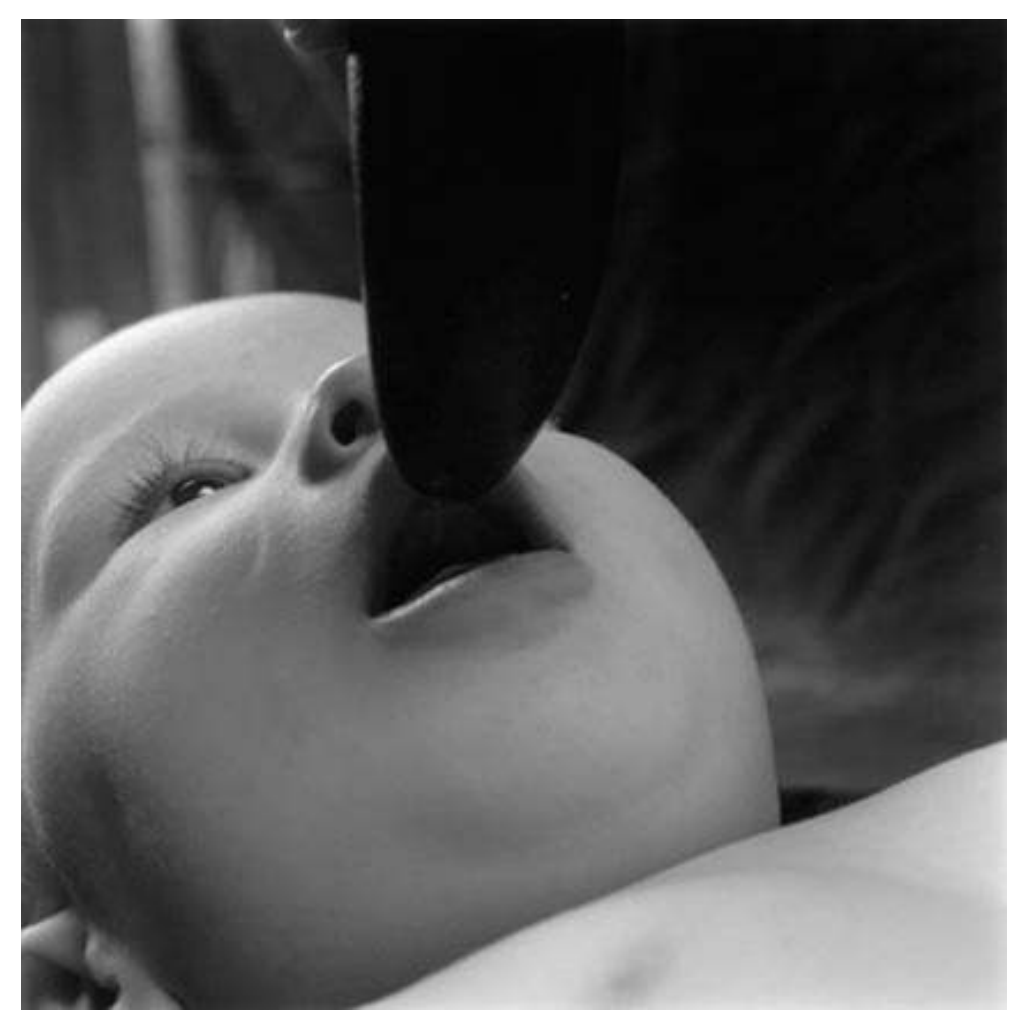

edited by Edward Leffingwell and Mario Cravo Neto, published by Aries Editora in Salvador, Brazil, 2002, Courtesy of Mario Cravo Neto's Estate

It is the lyricism and sculpturality of Cravo Neto's images that make this subversive nature so haunting and in ways affective. It is the way it creeps up on the viewer, like a specter that stands just below the surface that makes these images powerful commentaries on the history of racial discourse in Brazil and its dangerous long lasting legacy. The Black Atlantic archive is in Cravo Neto's images recuperated and reactivated in critical ways and given a new affective life that has much to bear on the contemporary both socially and imagetically.

\section{Conclusion}

Cravo Neto continued to create works until he died in 2009 ; his series have diverged and worked against earlier works like the Eternal Now series. Nevertheless, what I have attempted to show here is that the way his images dialog with the archive of the Black Atlantic and Brazilian racial history through lyricism and other aesthetic strategies shows the possibility of art to deal with histories of trauma and demand that we face them too.

Cravo Neto's images, affectively, re-invent the black body, by engaging the tradition that has usually registered it, but pushing against it, evoking its specter, but manipulating this affective power to subvert it. It proposes a new way to show and frame its viewing. The Benetton ad of the black mother and child and its persistent popularity in Brazil until today shows that the discourses of race are still present and this legacy remains an important feature of Brazilian society. The affective potential of 
Cravo Neto's images is to make this legacy visible and their poignant nature manifested, while highlighting also how it can be subverted and reconfigured.

\section{BIBLIOGRAPHY}

ANDERSON Susan M., Body to earth : three artists from Brazil, Cildo Meireles, Mario Cravo Neto, Tunga, January 13-February 20, 1993.

BARTHOLOMEu Cezar, "Mário Cravo Neto : a máscara é um olho", in Conexão Comunicação e Cultura, UCS, Caxias do Sul, Vol.6, n. 12, Jul/Dez., 2007, p. 21-28.

BARTHES Roland, Camera Lucida: Reflections on Photography, New York, Vintage Classics ; New edition, 2000.

CHIARELLI Tadeu, Arte Internacional Brasileira, São Paulo, Lemos Editorial, 2002.

CONDURU Roberto, Pérolas negras-primeiros fios: experiências artísticas e culturais nos fluxos entre África e Brasil, Rio de Janeiro, Ed UERJ, 2013.

CRAVO NETO Mario, Mário Cravo Neto, Introdução Rubens Fernandes Júnior, Salvador, Aries, 1995. DÁVILA Jerry, Diploma of Witnesses : Race and Policy in Brazil : 1917-1945, Durham, Duke University Press, 2003.

FREYRE, Gilberto, Casa Grande e Senzala, Los Angeles, University of California Press, 1986.

LEFFINGWELL Edward, “Report from Brazil : São Paulo Diary.", in Art in America 77, no. 1, January, 1999 , p. 55-66.

LEFFINGWELl Edward and CRAVO NETO Mario, The Eternal Now, Salvador, Aries Editora, 2002.

Los Angeles : Fisher Gallery, University of Southern California.

NETO Mario CRAVO; CASTRO RAMíREZ Fernando (texto y curadoria) ; Tucker, Anne Wilkes (texto y curadoria), La oscura piel de la luz : la obra fotográfica de Mario Cravo Neto. Caracas, Museo de Bellas Artes de Caracas, 2009.

MASSUmi Brian, 'The Autonomy of Affect', in Cultural Critique, No. 31, The Politics of Systems and Environments, Part II, Autumn, 1995, p. 83-109.

PINNEY Christopher, Photography and Anthropology, London, Reaktion Books, 2012.

SCIME Giulina (cur.), MARIO CRAVO NETO : The mystic photo, Brescia, Italy, PaciArte contemporary, 2009.

SKIDMORE Thomas, Black Into White: Race and Nationality in Brazilian Thought. Durham, Duke University Press, 1993.

wooD Marcus Black Milk: Imagining Slavery in the Visual Cultures of Brazil and 2013. America. UK :

Oxford University Press. 


\section{NOTES}

1. I would like to thank Christian Cravo for his generosity in allowing the reproduction of Mario Cravo Neto's photographs in this article. I would also like to thank Prof. Roberto Conduru for giving me the space to work on this topic during his graduate seminar at Southern Methodist University in the Spring of 2014, as well as his feedback and support. Furthermore, I want to thank my colleagues at the Art History program for their comments. All shortcomings of the work are of course my own.

This group of photographs is large and varied, what they share is essentially a photographic style. So although my focus is on this corpus, I will make a cut and only approach small constellations of photographs existing within this larger series that share beyond the stylistic commonality what I believe is a discursive commonality.

2. This discussion of the sculptural character of Cravo Neto's photographs is present in all discussions of the artist's work. For other interpretations of Mario Cravo Neto's oeuvre see the bibliography.

3. The exception here is Roberto Conduru, who explores the place and meaning of ritual in Cravo Neto's work and discusses how the characteristics of the Afro-Brazilian religions themselves have led to the configuration of the artist's images, specifically the relationship between the bodies and the objects, as well as the background and the figure. See : Conduru 2013.

4. The concept of punctum is a central point of Roland Barthes' Camera Lucida. As Barthes points out, while in some images it is the viewer's consciousness that searches and constructs meaning, there are some images where another "element which rises from the scene, shoots out $f$ it like an arrow, and pierces [the viewer]. A Latin word exist to designate this wound, this prick, this mark made by a pointed instrument : the word suits me all the better in that is also refers to the notion of punctuation, and because the photographs I am speaking of are in effect punctuated, sometimes even speckled with these sensitive points ; precisely these marks are so many points." I use the 2000 translated English version of Barthes Camera Lucida here (Barthes 2000, 26-27). I interpret punctum in Barthes here as the ability of specific photographs-and aspects within those photographs-to affect us in the sense Brian Massumi defines affect as an excess, as an intensity that is felt, but not necessarily easily interpreted (Massumi 1995, 85-7).

5. Regarding the concept of "whitening" and the racial history in Brazil see : Skidmore 1974 and Dávila 2003.

6. For a discussion of the theories of "racial democracy" and the discussion of the sexual exploitation of the slave owner over the female slaves in Brazil see : Freyre 1986, Skidmore 1993, Dávila 2003.

\section{ABSTRACTS}

Mario Cravo Neto is one of the most important contemporary photographers in Brazil. His works show a complex marriage of aesthetic lyricism, sculptural monumentality, and afro-Brazilian themes. In this paper, I am interested in comparisons that have been resisted by other scholars of Cravo Neto's work. Particularly, I focus on the way his photographs work against the documentary and ethnographic tradition in Brazil. By looking at a series of earlier works by Cravo Neto, I will argue that the legacy of the Black Atlantic archive is an undercurrent in the artist's work that at times transpires in eloquent ways. 
INDEX

Mots-clés: photographie, Brésil, Mario Cravo Neto, photographie ethnographique

Keywords: photography, Brazil, Mario Cravo Neto, ethnographic photography

\section{AUTHOR}

\section{ALICE HEEREN}

Alice Heeren is a PhD candidate at Southern Methodist University in the RASC/a: Rhetorics of Art, Space and Culture Program. Her research centers on affect theory and memory studies in relation to modern and contemporary art and architecture in Brazil and the construction of a national identity. She is currently the sub-editor of Latin American Visual Arts for the upcoming Routledge Encyclopedia of Modernism. 